International Journal of Social Sciences and Humanities
Available online at www.sciencescholar.us
Vol. 5 No. 3, December 2021, pages: 203-213
e-ISSN: 2550-7001, p-ISSN: 2550-701X
https://doi.org/10.53730/ijssh.v5n3.1835

\title{
Analysis of Public Service Performance through Strengthening Employee Motivation in the Organization and Society Sub- Sector in the National and Political Unity Agency of Maluku Province
}

Petronela Sahetapy a
Manuscript submitted: 18 September 2021, Manuscript revised: 27 October 2021, Accepted for publication: 09 November 2021
Corresponding Author a

International Journal of Social Sciences and Humanities (C) 2021.

This is an open access article under the CC BY-NC-ND license (https://creativecommons.org/licenses/by-nc-nd/4.0/).

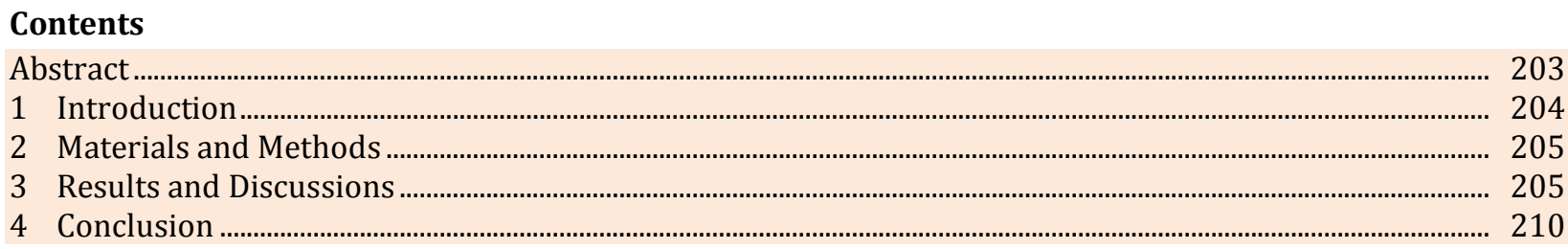

${ }^{\text {a }}$ Universitas Pattimura, Ambon, Indonesia 
Acknowledgments..

\section{Introduction}

Body Unity Nation and Politics province of Maluku as one of the government institutions are also duties organizes public services is expected to answer the demands in realizing the service the public that good. In the case of this related to motivation as one of the aspects that support the performance of services public, that the public service can encourage an employee to provide a public service of the best to the people because motivation is a tendency that arises in self somebody employees to provide services to meet the interests of the other people or many people and to donate their services to realize the welfare of the community.

Related to that point, one of the characteristics of motivating employees is to know and internalize the meaning of the work undertaken so that employees will perform the work following what it should be and employment in the government as a public servant. Then ideally, an employee should be able to work in a way serving the public interest. In addition, setting clear and clean public service goals, in which goal setting in public services can be done in various ways, one of which is by interpreting public services in terms of clear and clean and meaningful job expectations that can be realized in the public service process at Body Unity Nation and Politics province of Maluku.

In addition, employee interpersonal relationships can also improve employee performance, when each employee with complete desire, belief, and hope in making relationships at work will arise cooperation that will facilitate the completion of work tasks. According to Ibrahim et al., (2021), regulation is a form of delegation of authority and adjusting conditions to aspects of the bureaucratic structure. Interpersonal relationships also led to a solid bond to create a conducive working atmosphere in motivating employees to improve performance in doing the service of the public at the Agency Unitary Nation and Politics province of Maluku.

In connection with that, of the observations in particular on the Agency Unity of the Nation and Politics province of Maluku, it seems that carrying out duties and responsibilities of the organization and community is not yet fully accompanied by encouragement or strong motivation to realize the best public service. In contrast, the service performance public had not reached the expected purpose and would be the primary concern to be addressed (Herron \& Robinson Jr, 1993; Sandberg \& Hofer, 1987). Community groups oversee implementing social assistance programs carried out by the village government (Tuanaya et al., 2020). Thus, motivation in public services as one measure in an assessment system becomes a consideration that is expected to be realized through the performance of public services and is used as an encouragement by employees to produce a good performance in public services (Francois, 2000; Epple \& Romano, 1996). Strengthening the motivation is needed in improving the performance of servicing the public at the Agency Unitary Nation and Politics province of Maluku.

The government system should be put forward political authority and prioritize political commitment as one of the aspects of the matter. Characteristics in motivating employees are to know and internalize the meaning of the work undertaken so that employees will perform the work following what it should be, as well as employment in the government as a public servant, and then ideally an employee should be able to work in a way serving the public interest. The existing public service reform has not changed (Dwiyanti, 2019). The perspective of The New Public Service has many facets and demands recognition of the complex role played by the government (bureaucrats) in contemporary governance (Herizal et al., 2020).

A motive is a need that is stimulated is oriented to the purpose of the individual in achieving a sense of satisfaction (Sari Wijayanti, 2008). Meanwhile, Hasibuan (2008), asserts that motivation comes from the Latin word mover, which means encouragement or the provision of a driving force that creates one's work enthusiasm so that they want to work together, work effectively, and be integrated with all their efforts to achieve satisfaction. According to Matdoan et al. (2021), there are still gaps in 7 districts/cities in Maluku that have life expectancy below the national life expectancy rate. 
Sardiman (2020), suggests that motivation is the driving force to carry out activities to achieve goals. Motivation is a skill in directing employees and organizations to work successfully so that employees and organizational goals are simultaneously achieved (Hasibuan, 2008; Putra et al., 2020; Maesaroh et al., 2020). Maunah (2009), divides motivation into two parts, namely: intrinsic motivation and extrinsic motivation. Motivation Intrinsic motivation comes from within yourself, and extrinsic motivation is the motivation of the outer self of a person. So that organizational policy partnerships are a factor in implementing government organizational programs (Tuanaya et al., 2020).

\section{Materials and Methods}

This study was designed with quantitative methods, descriptive, and classified as applied research, (Phillippi \& Lauderdale, 2018; Porter et al., 2016; Marshall et al., 2013; Bengtsson, 2016), which applied research is research used to solve the problems within the organization or institution that is intended to answer a particular problem (Sujarweni, 2014). The operational definition of the variable aims to explain the meaning of the studied variable, besides being an element of research that tells how to measure a variable; in other words, it is a kind of implementation guide on how to measure a variable (Singarimbun \& Effendi, 2019).

Thus the operational definition of this research variable is stated as follows: Strengthening Employee Motivation (X) is a condition that moves employees to achieve the goals of their motives (Syafii et al., 2015; Rahimić et al., 2012; Leete, 2000). Measures of strengthening employee motivation include Desire (Valency), Confidence (Outcome Expectancy), and hope (Effort Expectancy) (Sobur, 2019). Improving Public Service Performance $(\mathrm{Y})$ is an effort on the ability of an employee to achieve reasonable work results or, more prominently, towards achieving organizational goals in public services (Schneider,1980). This public service performance measures results-oriented, namely Effectiveness, Productivity, Efficiency, Satisfaction, and Justice in the public service (Al-Hamid, 2021; Irfadat et al., 2020).

\section{Results and Discussions}

\section{Effectiveness}

Performance Public Service via Effectiveness received responses from respondents with the statement "Very Support (SM)" and Supports (M) "proved that the volume of work received by employees already following the ability to perform service to the community by $38 \%$. Every employee in the service to the public is as quickly as big as $43 \%$. The time given to carry out the public service is following the targets set at $41 \%$. The employee the right time to complete each activity on the public service by $50 \%$ was essential. Each employee can deal with and pass through obstacles in service, with both at $39 \%$. Average Achievement (CRr) of public service Performance through Effectiveness of $42.2 \%$ is in the range of $41 \%-60 \%$.

\section{Productivity}

Performance Services Public through Productivity got responses from respondents with the statement "Very Support (SM)" and Supports (M) "to prove that the employee can perform many tasks that are given service to the community by $57 \%$. The work of each employee is increasing in service to the community by $51 \%$. Each community service to be completed as quickly and precisely as big as $53 \%$ was essential. The employeeoriented on the achievement of the results of the service are adequate at $57 \%$. Each employee can realize the results of quality services by $46 \%$. Average Achievement (CRr) of Public Service Performance through Productivity of $52.8 \%$ is in the range of $41 \%-60 \%$.

Sahetapy, P. (2021). Analysis of public service performance through strengthening employee motivation in the organization and society sub-sector in the national and political unity agency of Maluku Province. International Journal of Social Sciences and Humanities, 5(3), 203-213. https://doi.org/10.53730/ijssh.v5n3.1835 


\section{Efficiency (Efficiency)}

Performance of Public Services through Efficiency received responses from respondents with the statement "Very Support (SM)" and Supports (M)" to prove that the employee saves time by either in performing its duties or service to the community by $31 \%$. Each employee uses a facility that is equipped to perform service to the community by $53 \%$. The employees were able to meet the target of fast service to the community by $48 \%$ that always tries to minimize obstacles in service to the community by $46 \%$. Either achieving the efficiency of work in service to the community by $47 \%$ was right. Average Achievement (CRr) of Public Service Performance through Efficiency of $45 \%$ is in the range of $41 \%-60 \%$.

\section{Satisfaction (Satisfaction)}

Public Service Performance through Satisfaction received responses from respondents with the statements "Highly Supporting (SM)" and Supporting (M)," proving that employees are aware that the community needs satisfaction with service results by $46 \%$. Each employee continues to strive to achieve service results that satisfy the community by $47 \%$. The employees feel satisfied with its work in giving service to the community by $48 \%$. The community feels satisfied with the results of the service that is received by $48 \%$. The employees continue to commit to producing the best service that satisfies the community by $55 \%$. Average Achievement (CRr) of Public Service Performance through Satisfaction of $48.8 \%$ is in the range of $41 \%-60 \%$.

\section{Justice (Equity)}

Performance Public Service through Justice received responses from respondents with the statement "Very Support (SM)" and Supports (M) " to prove that the employee puts service that is fair to the public by 51\%. Services provided justly received by both the public amounted to $53 \%$. Not discriminatory in providing services to the community by $57 \%$. The community feels they are treated fairly in the service by $46 \%$. Neither the employees nor the public was satisfied with the service results achieved by 53\%. Average Achievement (CRr) of Public Service Performance through Justice of $52 \%$ is in the range of $41 \%-60 \%$.

\section{Adaptation and interpretation}

In the adaptation and interpretation, the result of direct conversion percentage of respondents confirmed again through the accumulation of Achievement Percentage Average (AP CRR) and Interpretation Reinforcement Motivation Employees (X) and Performance Services Public (Y) as outlined in the table as follows.

Table 1

Adapted and interpreted

\begin{tabular}{ccc}
\hline \multicolumn{3}{c}{$\begin{array}{c}\text { Analysis of Public Service Performance Through Strengthening Employee Motivation at the Nati } \\
\text { onal and Political Unity Agency } \\
\text { Maluku Province }\end{array}$} \\
\hline Variable & Accumulated Percentage (AP) & Interpretation \\
\hline I. Strengthening Employee Motivation (X) & $50 \%$ & Enough \\
II. Public Service Performance (Y) & $48.16 \%$ & Enough \\
AP CRr & $49.08 \%$ & Enough \\
\hline
\end{tabular}

Source: Data Processing Results, 2021

The adaptations and interpretations show that Reinforcement of Motivation received positive support of 50\% in the category of Enough, and Public Service Performance received positive support of $48.16 \%$ in the category of Enough. By this, it is presentation "Performance Services Public Through Strengthening Motivation Employees On Board Unity of the Nation, and Politics Maluku province were" in the categorical Accumulated Percentage Achievement Average (AP CRR) amounted to 49.08\%. 


\section{Relationship between variables}

The relationship between Strengthening Employee Motivation and Public Service Performance is seen through crossing the Accumulative Score (ScA), which leads to the Relationship Score (S cH) and Cross Accumulation of Relationship Score $(\mathrm{A} \mathrm{ScH})$ and the percentage of Cross Relationship Score (P ScH) which is totaled (P ScTH) as a result of the relationship between the two variables as a percentage as stated in the table as follows.

Table 2

Relationship between variables

\begin{tabular}{|c|c|c|c|c|c|}
\hline \multicolumn{6}{|c|}{$\begin{array}{l}\text { Analysis of Public Service Performance Through Strengthening Employee } \\
\text { Motivation at the National and Political Unity Agency } \\
\text { Maluku Province }\end{array}$} \\
\hline \multicolumn{6}{|c|}{ Relationship Between Variables } \\
\hline \multicolumn{2}{|c|}{$\begin{array}{c}\text { Bound Variable } \\
\text { Public Service Performance } \\
\text { Ce }(Y)\end{array}$} & \multicolumn{2}{|c|}{$\mathrm{S}_{\mathrm{CH}}$} & \multicolumn{2}{|c|}{$\begin{array}{l}\text { Independent Variable } \\
\text { Strengthening Employee } \\
\text { Motivation }(\mathrm{X})\end{array}$} \\
\hline ScA ? & 173 & \multicolumn{2}{|c|}{485} & 112 & ? $\mathrm{ScA}$ \\
\hline $\mathrm{ScH}$ ? & 485 & \multicolumn{2}{|c|}{$\mathrm{AScH}$} & 485 & ? $\mathrm{ScH}$ \\
\hline \multirow[t]{2}{*}{$\mathrm{AScH}$} & 658 ? & 560 & 519 & ?597 & \multirow[t]{2}{*}{ ? $\mathrm{AScH}$} \\
\hline & 19,0312 & ? 152,25 & 139,5? & 17,4375 & \\
\hline \multirow[t]{2}{*}{$\mathrm{PScH}$ ? } & $63,43 \%$ & \multicolumn{2}{|c|}{30} & $58,12 \%$ & ? $\mathrm{PScH}$ \\
\hline & & \multicolumn{2}{|c|}{$\mathrm{X}$ ? $60,77 \%$ ? $\mathrm{Y}$} & \multicolumn{2}{|c|}{ ?PScTH1 } \\
\hline
\end{tabular}

Source: Data Processing Results, 2021

It seemed clear that Performance Services Public Through Strengthening Motivation Employees At the National Unity and Political Maluku province of the results of crossing proven Score Accumulated Strengthening Motivation Employee of 112 and Score Accumulated Performance Services Public of 173 with scores Relation 485. While Accumulated Cross Score Relations Reinforcement Motivation Employee to Public Service Performance of 519 (58.12\%). At the same time, Accumulated Cross Score Relations Performance Services Public to Strengthen Motivation Officer of 560 (63.43\%).

The relationship between Strengthening Employee Motivation and Public Service Performance according to the Cross Percentage of Total Relationship Score (P ScTH1) of $60.77 \%$ is above the middle limit with a balanced number of 1 (one). It leads to the amalgamation of Accumulated Percentage and Cross Percentage of Relationship Scores to achieve Accumulation Percentage of Average Achievement and Cross Percentage of Total Relationship Score (P ScTH2) with a balanced number of 2 (two) which will be converted sociometrically based on the Preferred Status Index (ISP) in determining the priority of follow- up.

\section{Conversion sociometric and determination of priorities}

As the final stage of the Performance Analysis Public Service Through Strengthening Motivation Employees On Board Unity of the Nation and Politics Maluku importance of conversion and prioritization aiming and useful for follow-up increase in Strengthening Motivation Employee and Performance Services Public On-Board Unit Nation and Politics province of Maluku as mentioned in the table as follows.

Sahetapy, P. (2021). Analysis of public service performance through strengthening employee motivation in the organization and society sub-sector in the national and political unity agency of Maluku Province. International Journal of Social Sciences and Humanities, 5(3), 203-213. https://doi.org/10.53730/ijssh.v5n3.1835 
Table 3

Conversion sociometric and determination of priorities

\begin{tabular}{ccccc}
\hline \multicolumn{5}{c}{ Analysis of Public Service Performance Through Strengthening Employee Motivation at the Na } \\
tional and Political Unity Agency \\
Maluku Province
\end{tabular}

Source: Data Processing Results, 2021

The results of the conversion and determination of priorities in question show that the performance of public services through strengthening employee motivation at the National Unity and Political Agency of Maluku Province focuses on the percentage of $54.06 \%$ of Strengthening Employee Motivation can be increased by the Preferred Status Index (ISP: 0.864) as Priority I and from Public Service Performance is 55.79\% with Preferred Status Index (ISP: 0.923) as Priority II by combining the Accumulated Percentage of Average Achievement and Cross Percentage of Total Relationship Score (P ScTH2) of 79.46 \% with Status Index Choice (ISP:0.740) or $74 \%$ as a contribution to be followed up by considering the intervention of other factors outside the Percentative and Sociometric Relationship Model of $26 \%$. Analysis of Public Service Performance Through Employee Motivation In the National Unity and Political Maluku Province are discussed following the findings of the study are concrete which includes the strengthening of motivation Employees (X) and Public Service Performance $(\mathrm{Y})$ as well as the relationship between the two variables (XY) within the scope of Sosiometrik.

\section{Strengthening employee motivation $(X)$}

Strengthening Motivation Employees In the Form of Interest (Valency) have the support they are optimistic that the employees are driven by a will that is high in advance of service and accompanied by a strong desire to achieve the purpose of serving as driven by a great desire realizing and following the service change. They carry out tasks with responsibilities high in service and continue to strive to provide the best service. The concrete facts can be seen from the Average Achievement of Reinforcement of Employee Motivation in the Form of Desire of $51.8 \%$ in the range of $41 \%$ - $60 \%$ in the "Enough" category.

Strengthening Motivation Employees In Shape Confidence (Outcome Expectancy) support that is positive, i.e., the employees are sure to apply the rules of service is appropriate and sufficient, which is where they continue to build confidence in carrying out and executing the assignment. Besides, they can fulfill the promised service because a strong belief drives them to achieve service goals that can provide satisfaction from service results. Fact concrete look of achievement average (CRR) Strengthening Motivation Employees In Shape Confidence at $49.8 \%$ is in the range $41 \%$ - $60 \%$ categorized "Enough." 
They are strengthening Motivation Employees In Shape Hope (Effort Expectancy) support that is positive, that the employees hope that the firm will speak of success in carrying out the service following their needs and effort embody hope in concrete in service. They continue to build pleasing cooperation in service to achieve expectations and remain consistent in carrying out service tasks as expected, and they are expected to be able to face and resolve problems that arise in service. The concrete facts can be seen from the Average Achievement (CRr) of Strengthening Employee Motivation in the Form of Expectations of $48.4 \%$ in the range of $41 \%-60 \%$ in the "Enough" category.

\section{Public service performance (Y)}

Performance Services Public In Shape Effectiveness gets the support that positively proves that the volume of work that the employee receives is already following the ability to perform services to the public. They do a service to the public quickly, and the time given to carry out the public service follows the targets set. The employee has the right time to complete each activity on the public service, and they can face and pass the barriers in service. The concrete facts can be seen from the Average Achievement (CRr) of Public Service Performance in the Form of Effectiveness of $42.2 \%$, which is in the range of $41 \%-60 \%$ in the "Enough" category.

Public Service Performance In The Form Of Productivity (Productivication) gained the support, which positively proves that the employee can perform many duties that provide services to the public. Their work is increasing in service to the community and can be completed quickly and precisely. The employee-oriented on the achievement of the service results are adequate, and they were able to realize the service results are qualified. The concrete facts can be seen from the Average Achievement (CRr) of Public Service Performance in the Form of Productivity of 52.8\%, which is in the range of $41 \%-60 \%$ in the "Enough" category.

Performance Services Public In Shape Efficiency obtain the support that positively proves that the employee saves time by carrying out duties and service to the community and using the facilities that are equipped to perform service to the community. The employees can meet the target of fast service to the community, and they always try to minimize obstacles in service to the community so that work efficiency in service to the community is achieved correctly. The concrete facts can be seen from the Average Achievement (CRr) of Public Service Performance in the Form of Efficiency of $45 \%$ in the range of $41 \%-60 \%$ categorized as "Enough."

Performance Services Public In Shape Satisfaction gained the support which positively proves that the employees realize that satisfaction will result from the vital service community, and they continue to realize the results of services to satisfy the public. The employee is satisfied with his work in providing services to the public, and people are satisfied with the results of the service received so that they continue to build commitment to producing the best services that satisfy the community. Fact concrete look of achievement average (CRR) Performance Services Public Satisfaction in the Form 48.8\% is in the range 41\%- $60 \%$ categorized "Enough."

Performance of services the public through Justice gained the support, which is optimistic that the employees put forward the fair service to the community and are given relatively well-received by the community. They are non-discriminatory in giving service to the community, and people feel treated relatively in the ministry; that is, both the employees and the community feel satisfied with the service results are achieved. Visible concrete Accomplishment average (CRR) Performance Services Public In the Form of Justice of $52 \%$ is in the range of $41 \%-60 \%$ categorized "Enough."

\section{Relationship between strengthening employee motivation and public service performance (XY)}

Research is managed to describe the operational concept of theory Strengthening Motivation Employees of Sobur (2019), as well as theoretical concepts Performance Public Service of Mukarom \& Laksana (2016), which is practically proven that the performance of Public Service Through Motivation Employees At the National Unity and Political Maluku have done quite well. The accumulation Cross relationship Percentage Score Silang relations illustrate the relationship between Motivation Employees with performance Services Public amounted to $60.77 \%$.

Sahetapy, P. (2021). Analysis of public service performance through strengthening employee motivation in the organization and society sub-sector in the national and political unity agency of Maluku Province. International Journal of Social Sciences and Humanities, 5(3), 203-213. https://doi.org/10.53730/ijssh.v5n3.1835 
Relationships that are positive as fairness which proceed in achieving the best results in terms of strengthening Motivation Employee and Performance Public Service, which has been proven from the merger to make sure that the Reinforcement Motivation Employees give contributions that "Strong" with the value of the conversion is Sosiometrik ISP 0.740 or by $74 \%$ for public service performance, though still there is another factor intervention by $26 \%$ beyond presentation relationship model and sociometric.

In terms of prioritization, improvement is still needed in strengthening employee motivation because the A $\mathrm{P} \mathrm{P} \mathrm{ScH}$ score is $54.06 \%$ compared to an increase in the ISP value of 0.864 (84.6\%). Likewise with Performance Services Public also requires an increase because the value of A P P Sch $55.79 \%$ also rose compared with the value ISP $0.923(92.3 \%)$. In the sense that the normalization of the increase that needs to be done for Strengthening Employee Motivation is 30.54\%, and the normalization of the increase that needs to be done for the Public Service Performance is $36.51 \%$. While the value of A P C Rr \& P ScTH $79.46 \%$ decrease compared with the value ISP 0.740 (74\%), which means that the normalization of Strengthening Motivation Employees with consideration of 5\% of the value of A P C Rr \& P ScTH provide contribute for Performance Services Public by $74 \%$.

More further described in the model Persentatif and Sosiometrik relationship Strengthening Employee Motivation and Performance of Public Service following the study results were achieved as follows. It seems that the relationship Persentatif (P) and Sosiometrik (ISP) which positively contributes to the normalization of Improvement (NP), which focuses on strengthening motivation Employees and Performance Public Service, which is where the normalization of the increase is intended for Strengthening Motivation Employees focus on Desire (Valency), Confidence, Hope (Effort Expectancy) as a priority I (First) and performance Services Public focus on effectiveness, productivity, Efficiency, Satisfaction, and Justice (Equity) as Priority II (Both) through the follow-up process.

\section{Conclusion}

Underlie the results and discussion of appropriate analysis performance Services Public Through Strengthening Motivation Employees On Board National Unity and Political Maluku province can put forward some conclusions as follows:

a) Performance Services Public through Strengthening Motivation Employees are revealed Desire, Confidence (Outcome Expectancy), and Hope (Effort Expectancy) support Effectiveness, Productivity (Productivication), efficiency (Efficiency), Satisfaction (Satisfaction), and Justice (Equity).

b) Desire, Confidence (Outcome Expectancy), and Hope (Effort Expectancy) are very decisive in strengthening Motivation Employees and can provide the impact that is favorable for the performance of public service includes Effectiveness, Productivity, Efficiency, Satisfaction, and Justice.

c) Desire (Valency) dominates Confidence (Outcome Expectancy), and Hope (Effort Expectancy) in Strengthening Motivation Employees and Productivity (Productivication) dominate Effectiveness (Effectiveness), efficiency, Satisfaction (Satisfaction), and Justice in Performance Services Public.

d) Strengthening Motivation Employees are dominated by the desire (Valency), which can be done with good and coupled with Confidence (Outcome Expectancy) and Hope (Effort Expectancy) will improve the performance of Services Public which is dominated by Productivity and followed with Effectiveness, Efficiency, Satisfaction, and Justice.

e) Strengthening Employee Motivation has a "Strong" relationship and contribution to Public Service Performance Percentative and Sociometric based on the Preferred Status Index (ISP: 0.740) or 74\% with $26 \%$ other factor interventions.

f) The follow-up Strengthening Employee Motivation and Performance Service Public in the form of normalization of the increase which is realized through sociogram as a result that is sketched in hopes accomplished and achieved in the maximum.

g) It was proven that the findings of this study give priority to the normalization of the increase in Employee Motivation and Performance Strengthening the Public Service as a follow-up process with a trend that will lead to the maximization and the implications for the development and advancement of services of public On-Board Unit Nation and Politics province of Maluku. 
Acknowledgments

The authors appreciate all support and contributions both academic and financial support so that this project can be done as expected. Without that support, we will not be able to complete as intended before.

Sahetapy, P. (2021). Analysis of public service performance through strengthening employee motivation in the organization and society sub-sector in the national and political unity agency of Maluku Province. International Journal of Social Sciences and Humanities, 5(3), 203-213. https://doi.org/10.53730/ijssh.v5n3.1835 


\section{References}

Al-Hamid, R. (2021). Bureaucracy culture change of administrative services on COVID-19 pandemic era. International Journal of Social Sciences and Humanities, 5(3), 192-202. https://doi.org/10.53730/ijssh.v5n3.1720

Bengtsson, M. (2016). How to plan and perform a qualitative study using content analysis. NursingPlus Open, 2, 8-14. https://doi.org/10.1016/j.npls.2016.01.001

Dwiyanti, N. (2019). Interaksi Komunikatif di Pelayanan Publik Unit Transfusi Darah Kabupaten Jember: Suatu Kajian Etnografi Komunikasi (Doctoral dissertation, Fakultas Ilmu Budaya).

Epple, D., \& Romano, R. E. (1996). Ends against the middle: Determining public service provision when there are private alternatives. Journal of Public Economics, 62(3), 297-325. https://doi.org/10.1016/00472727(95)01540-X

Francois, P. (2000). 'Public service motivation'as an argument for government provision. Journal of Public Economics, 78(3), 275-299. https://doi.org/10.1016/S0047-2727(00)00075-X

Hasibuan, H. M. S. P. (2008). Organisasi dan motivasi: dasar peningkatan produktivitas.

Herizal, H., Mukhrijal, M., \& Wance, M. (2020). Pendekatan akuntabilitas pelayanan publik dalam mengikuti perubahan paradigma baru administrasi publik. Journal of Governance and Social Policy, 1(1).

Herron, L., \& Robinson Jr, R. B. (1993). A structural model of the effects of entrepreneurial characteristics on venture performance. Journal of business venturing, 8(3), 281-294. https://doi.org/10.1016/08839026(93)90032-Z

Ibrahim, A. H., Husen, T., Hariyatmoko, K., Djae, R. M., \& Wance, M. (2021). Implementation of Standard Operational Procedures (SOP) Information Dissemination of BMKG Tsunami Early Warning at the Geophysical Statium of Ternate. Annals of the Romanian Society for Cell Biology, 2317-2327.

Irfadat, T. . ., Nurlaila, N. ., Haeril, H. ., \& Tauhid, T. . (2020). Dimensions of public services: A portrait of irony facilities for disabilities. International Journal of Social Sciences and Humanities, 4(3), 130-141. https://doi.org/10.29332/ijssh.v4n3.471

Leete, L. (2000). Wage equity and employee motivation in nonprofit and for-profit organizations. Journal of Economic Behavior \& Organization, 43(4), 423-446. https://doi.org/10.1016/S0167-2681(00)00129-3

Maesaroh, M., Akbar, B., Murwitaningsih, S., Elvianasti, M., \& Aslan, A. (2020). Understanding Students Characteristics of Graduates in Biological Education Department (A Case Study Done in Muhammadiyah University Prof. Dr. Hamka). International Journal of Psychosocial Rehabilitation, 24(06), 1839-1845.

Marshall, B., Cardon, P., Poddar, A., \& Fontenot, R. (2013). Does sample size matter in qualitative research?: A review of qualitative interviews in IS research. Journal of computer information systems, 54(1), 11-22.

Matdoan, M. Y., Wance, M., \& Balami, A. M. (2021). Ridge regression modeling in overcoming multicollinearity problems in multiple linear regression models (case study: Life expectancy in Maluku Province). In AIP Conference Proceedings (Vol. 2360, No. 1, p. 020014). AIP Publishing LLC.

Maunah, B. (2009). Ilmu pendidikan.

Mukarom, Z., \& Laksana, M. W. (2016). Building Public Service Performance. Bandung: Loyal Reader CV.

Phillippi, J., \& Lauderdale, J. (2018). A guide to field notes for qualitative research: Context and conversation. Qualitative health research, 28(3), 381-388.

Porter, W. W., Graham, C. R., Bodily, R. G., \& Sandberg, D. S. (2016). A qualitative analysis of institutional drivers and barriers to blended learning adoption in higher education. The internet and Higher education, 28, 17-27. https://doi.org/10.1016/j.iheduc.2015.08.003

Putra, P., Setianto, A. Y., \& Hafiz, A. (2020). Etnopedagogic Studies In Character Education In The Millinneal Era: Case Study Min 1 Sambas. Al-Bidayah: jurnal pendidikan dasar Islam, 12(2), 237-252.

Rahimić, Z., Resić, E., \& Kožo, A. (2012). Determining the level of management competences in the process of employee motivation. Procedia-Social and Behavioral Sciences, 41, 535-543. https://doi.org/10.1016/j.sbspro.2012.04.066

Sandberg, W. R., \& Hofer, C. W. (1987). Improving new venture performance: The role of strategy, industry structure, and the entrepreneur. Journal of Business venturing, 2(1), 5-28. https://doi.org/10.1016/08839026(87)90016-4

Sardiman, A. M. (2020). Interaksi \& motivasi belajar mengajar.

Sari Wijayanti, I. D. (2008). Manajemen. 
Schneider, B. (1980). The service organization: climate is crucial. Organizational dynamics, 9(2), 52-65. https://doi.org/10.1016/0090-2616(80)90040-6

Singarimbun, M., \& Effendi, S. (2019). Metode penelitian survai.

Sobur, A. (2019). Psikologi Umum, Edisi Revisi.

Sujarweni, V. W. (2014). Metodologi penelitian keperawatan.

Syafii, L. I., Thoyib, A., \& Nimran, U. (2015). The role of corporate culture and employee motivation as a mediating variable of leadership style related with the employee performance (studies in Perum Perhutani). Procedia-Social and Behavioral Sciences, 211, 1142-1147. https://doi.org/10.1016/j.sbspro.2015.11.152

Tuanaya, W., Tuhumury, J. J., \& Wance, M. (2020). Management Model And Village Fund Allocation During Pandemic Covid-19 In Waiheru Village Ambon Cityindonesia. PalArch's Journal of Archaeology of Egypt/Egyptology, 17(7), 13357-13369.

\section{Biography of Author}

\begin{tabular}{|l|l|}
\hline \hline & $\begin{array}{l}\text { Petronela Sahetapy, Lecturer of Public Administration, Faculty of Social and } \\
\text { Political Sciences, Universitas Pattimura, Ambon, Indonesia. } \\
\text { Email: nettycorputty@gmail.com }\end{array}$ \\
\hline
\end{tabular}

Sahetapy, P. (2021). Analysis of public service performance through strengthening employee motivation in the organization and society sub-sector in the national and political unity agency of Maluku Province. International Journal of Social Sciences and Humanities, 5(3), 203-213. https://doi.org/10.53730/ijssh.v5n3.1835 